\title{
Biological Traits and Life Table Parameters A and B Biotype of Bemisia tabaci (Genn.) on Cotton and Rapeseed
}

\author{
Mohammad Amin Samih ${ }^{1}$, Mehdi Zarabi ${ }^{2}$, Maryam Yazdani ${ }^{3}$ and Mohammad Rouhani ${ }^{* *}$ \\ ${ }^{I}$ Department of Plant Protection; Faculty of Agriculture; Vali-e-Asr University; Rafsanjan - Iran. ${ }^{2}$ Department of \\ Plant Protection; College of Plant and Animal Sciences; Abureihan campus of Agriculture; University of Tehran; \\ Iran. School of Agriculture, Food and Wine; University of Adelaide; South Australia - Australia. ${ }^{4}$ Department of \\ Plant Protection; Faculty of Agriculture; Razi University; Kermanshah - Iran
}

\begin{abstract}
The aim of this work was to construct life table of Bemisia tabaci (Gen.) A and B (silverleaf whitefly B. argentifolii Bellows and Perring) biotype (Hem.: Aleyrodidae) on two host plants; cotton, (Gossypium hirsutum L.) and rapeseed, (Brassica napus $L$.). Experiments were conducted in a growth chamber under $24 \pm 2{ }^{\circ} \mathrm{C}, 55 \pm 3 \% \mathrm{RH}$ and 16:8 (L:D) h photoperiod on caged plants of cotton G. hirsutum L. (Varamin 76 variety) and rapeseed B. napus $L$. (global variety. The intrinsic rate of natural increase $\left(r_{m}\right)$, net reproductive rate $\left(R_{0}\right)$ and mean generation time $(T)$ for B. tabaci A biotype was 0.1010 females per female per day, 18.4075 females per female and 30.079 day (d) on cotton; 0.1286, 30.6760 and $26.77 d$ on rapeseed; and for $B$ biotype (B. argentifolii) those above respective parameters averaged 0.1033, 27.8426 and $32.74 d$ on cotton and 0.1750, 40.75 and $21.27 d$ on rapeseed. The total survival of $A$ and $B$ biotype from the egg to adult on cotton was 22.08 and 22.25 , respectively. The results showed significant differences between the two biotype reared on either host plant for gross reproductive rate (GRR), net reproductive rate $\left(R_{0}\right.$ or $\left.N R R\right)$, intrinsic rates of increase $\left(r_{m}\right)$, finite rate of increase $(\lambda)$, doubling time $(D T)$ and mean generation times $\left(T_{c}\right)$. To obtain a better understanding of the biology of these biotypes, Stable age distribution $\left(C_{x}\right)$ and some other aspects of life history related to their hosts were also studied. Based upon the results, both biotypes showed a greater reproduction capacity on rapeseed than on cotton. Thus, rapeseed was more suitable host than cotton for two biotypes and this was an important factor in host plant selection for optimizing the control strategies of these major pests.
\end{abstract}

Key words: Bemisia argentifolii, Bemisia tabaci, Cotton, Life-table, Rapeseed

\section{INTRODUCTION}

The silverleaf whitefly, Bemisia argentifolii Bellows and Perring (Bellows et al. 1994), which was called B-biotype of B. tabaci (Gennadius) (Hemiptera: Aleyrodidae) (Byrne and Miller 1990) and cotton whitefly B. tabaci (Genn.) are extreme economic pests for many crops in the world (Rosell et al. 1997; Oliveira et al. 2001; Perring 2001; Musa and Ren 2005; Kakimoto et al. 2007). However, there is some doubt whether $B$. argentifolii is a separated species or a strain of $B$. tabaci (Brown et al. 1995; Calvitti and Remotti 1998, Dinsdale et al. 2010). Following the description of the $\mathrm{B}$ biotype searching for and describing $B$. tabaci biotypes became something of a cottage industry, with somewhere between 33 and 38 having been described to-date (Xu et al. 2010; Dinsdale et al. 2010). The evidence for species status within $B$. tabaci complex has been bolstered by Dinsdale et al. (2010) using a DNA barcoding method. De Barro et al. (2011) have

*Author for correspondence: Rouhani_valiasr@yahoo.com 
reported that Bemisia tabaci has long been considered a complex of 11 well-defined highlevel groups containing at least 24 morphologically indistinguishable species.

The economical losses is caused by the whiteflies directly by sucking the plant sap (Musa and Ren 2005), or indirectly through the transmission of plant viruses (Rubinstein et al. 1999; Jones 2003). In addition both adults and nymphs excrete honeydew, which can promote the growth of sooty moulds, which affect the market price of the product, and reduce plant photosynthesis and effectiveness of insecticides (Gerling et al. 1980; Palumbo et al. 2000).

Main factors of regulating the whiteflies biology and population dynamics are temperature (Enkegaard 1993; Cui et al. 2008; Guo et al. 2012), host plant suitability (Yano 2003; Kakimoto et al. 2007), natural enemies (Liu and Stansly 1998; Headrick et al. 1999; NavaCamberos et al. 2001) and management practices (Musa and Ren 2005). However, chemical control approaches are still valuable integrated pest management (IPM) tools that help to maintain or improve crop yield. Chemical control of adult and immature stages is difficult, because they live underside of the leaves, have high reproductive rate and feed on wide range of hosts (Mound and Halsey 1978).

Cotton and rapeseed are widely cultivated in Iran as a supplementary source of fiber and oil. They are considered to play an important role in human nutrition. The B. tabaci and $B$. argentifolii were first reported in cotton fields of Iran by Kiriukhin (1947) and Samih et al. (2006), respectively. These two biotypes are also common pests of cotton and rapeseed in Iran, which cause serious damage (Samih and Izadi 2006). Also, both of them are key pests on greenhouse plants.

The selection of simple demographic models such as life tables provides the most comprehensive portrayal of biology, population dynamics, and survival, development, and reproduction capabilities of a population under various conditions that can be used subsequently as a tool in designing of pest management strategies (Musa and Ren 2005). The aim of this study was to investigate the development and reproduction of cotton and silverleaf whiteflies on the two host plants, cotton (Gossypium hirsutum L. (Malvaceae)) and rapeseed (Brassica napus L. (Brassicaceae)) in order to understand its biological attributes and potential as a basis for sound pest management strategies.

\section{MATERIALS AND METHODS}

\section{Experimental plant and insect}

The seedlings of cotton ( $G$. hirsutum L variety, Varamine 76) and rapeseed (B. napus L. variety Global) were planted in flower pot. Plants were grown in a chamber at $25^{\circ} \mathrm{C}$ with $16: 8 \mathrm{~h}(\mathrm{~L}: \mathrm{D})$ photoperiod. The colonies of B. tabaci A and B (B. argentifolii) biotype were collected from the cotton fields in seven provinces (Fars, Golestan, Kerman, Markazi, Qom, Semnan and Tehran) in Iran. The purity of adult population of the species was checked using the RAPD-PCR technique (Samih et al. 2006; Samih et al. 2007). The whiteflies were selected from a continuous stock colonies, which were maintained under controlled conditions in environment growth chamber at $24 \pm$ $2^{\circ} \mathrm{C}$ with $65 \pm 3 \%$ relative humidity and $16: 8 \mathrm{~h}(\mathrm{~L}$ : D) on cotton. Each biotype was reared on both cotton and rapeseed for three generations separately and were used in the experiments. Overall, four treatments were prepared as following: 1- B biotype reared on rapeseed 2- B biotype reared on cotton 3- A biotype reared on rapeseed 4- A biotype reared on cotton.

\section{Development and survival of immature}

The experimental design followed the approach of Wang and Tsai (1996). To assess the development and survival of immature, 50 pairs of whitefly adults were aspirated from the rearing stock colony into a Plexiglas's cage $(25 \times 60 \mathrm{~cm})$. After $4 \mathrm{~h}$, the whitefly adults were removed. The number of eggs was 50 eggs per plant and biotype. A minimum of four replications was used per treatment (in total $\geq 200$ eggs per treatment) and each replication was formed by one plant. Following eclosion, after crawlers settled down on the leaf surface, each first instar nymph was encircled with a felt tip pen and numbered by digital microscope Dino (connectable to notebook). Development and survival were recorded at $24 \mathrm{~h}$ intervals. When the whitefly reached the red-eyed pupa stage, the leaves were detached from the plant and were placed in plastic cages $(13 \times 10 \times 3 \mathrm{~cm})$, which were covered with fine mesh cloth for ventilation. Experiments were conducted in a growth chamber under $24 \pm 2^{\circ} \mathrm{C}, 55$ $\pm 3 \% \mathrm{RH}$ and 16:8 (L: D)h photoperiod. The 
percentages of survival, sex ratio and developmental time were calculated by Excel and analyzed by using of SPSS 16 (SPSS Inc., Chicago, IL, USA).

\section{Life table and demographic parameters}

The newly emerged whitefly adults from the cohort population were separated according to sex. Each pair of whitefly (female and male) was placed in an individual rearing plastic cage $(13 \times$ $10 \times 3 \mathrm{~cm})$ containing treated leaf. Sixteen cages were used for each treatment and repeated for four times. Every $24 \mathrm{~h}$, female were transferred to a new leaf and the laid eggs were counted under a stereomicroscope. Daily observations were recorded until the death of all the females. Numbers of newly laid eggs and the life span of the female adults were recorded daily to calculate the fecundity and longevity, respectively. Females that died within the first $24 \mathrm{~h}$ of experiment or those produced no eggs, were excluded from the analysis. The bioassay plants were kept in the same experimental conditions as described above.

\section{Life table analysis}

The stable population model of Lotka $\sum_{\mathrm{x}=0}^{\omega} \mathrm{e}^{-\mathrm{rx}} \mathrm{l}_{\mathrm{x}} \mathrm{m}_{\mathrm{x}}=1$ is a basic quantitative means for describing the population dynamics. The basic assumptions of this demographic model are the stability of birth and mortality rates, lack of immigration and considering of only one sex (female). The survival at the corresponding time (lx) and the number of female eggs laid per female per day according to sex ratio $\left(\mathrm{m}_{\mathrm{x}}\right)$ for each age interval $(x)$ per day was the basic values of demographic parameters. From the fertility and survival schedules, population growth parameters were calculated using the following formula as suggested by Carey (1993), according to the method of Birch (1948) and Lin (1964).

Intrinsic rate of increase $(\mathrm{r})(1 \mathrm{t})=\sum_{\mathrm{x}=0}^{\omega} \mathrm{e}^{-\mathrm{rx}} 1_{\mathrm{x}} \mathrm{m}_{\mathrm{x}}=1$;

Finite rate of increase $(\lambda)$ (per day) $=\lambda=\mathrm{e}^{\mathrm{r}}$; Net reproductive rate (NRR) (eggs per female);= $\mathrm{R}_{0}=\sum_{\mathrm{x}=\alpha}^{\beta} 1_{\mathrm{x}} \mathrm{m}_{\mathrm{x}} ;$ Mean generation time, $(\mathrm{T})($ day $),=$
$\mathrm{T}=\frac{\ln \left(\mathrm{R}_{0}\right)}{\mathrm{r}} ;$ Doubling time, $(\mathrm{DT})($ day $),=\mathrm{DT}=\frac{\ln 2}{\mathrm{r}}$

$\alpha=$ age of first reproduction; $\beta=$ age of last reproduction; $\omega=$ last possible day of life; $\mathrm{x}=$ age in days; $\mathrm{l} x=$ survivorship at the corresponding time $\mathrm{mx}=$ number of female according to sex ratio laid per female per day

The means and standard errors of the life table parameters were estimated by using the jackknife method. For the statistical analysis, each mean value was shown with its standard error $( \pm$ SEM). The effect of host plant on developmental time, reproduction period and adult longevity were analyzed with two-way ANOVA, in which there were two factors: whiteflies and plants, each with two levels (A and B biotype in the first, and cotton and rapeseed in the second). If significance differences were detected, multiple comparisons were made using the least significant difference test (LSD) procedure $(P<0.05)$. Statistical analysis was carried out using SPSS 16 software. Differences in $\mathrm{R}_{0}, \mathrm{Tc}, \lambda$, dt and $\mathrm{r}_{\mathrm{m}}$ values were tested for the significance by estimating the variances through the jackknife procedure (Meyer et al. 1986; Maia et al. 2000). The jackknife procedure was used to estimate the variance for $r_{m}$ and the other population parameters (Meyer et al. 1986). Algorithms for jackknife estimating of the means and variances were described only for $r_{m}$. Similar procedures were used for the other parameters $\left(\mathrm{R}_{0}, \mathrm{~T}_{\mathrm{c}}, \lambda\right.$, and $\left.\mathrm{DT}\right)$. Square root transformed of data was analyzed by SPSS 16 software. Demographic parameters were subjected to two-way analysis of variance, followed by LSD multiple and Duncan's range test $(P=0.05)$.

\section{RESULTS}

In this study, B and A biotype completed their development and produced offspring on cotton and rapeseed.

\section{Development time and longevity}

Developmental time of different immature stages and adult longevity of B and A biotype on cotton are presented in Table 1. Evidently, there were no significant differences for both the biotypes between developmental time for the immature stages (pre-adult duration) on the cotton according to ANOVA. The egg-stage of both $\mathrm{B}$ and $\mathrm{A}$ biotype took 10.75 and 10.58 days, respectively at $24^{\circ} \mathrm{C}$. In both biotype, developmental period of the settled $1^{\text {st }}$ instars was on average $4-5$ days that for the $2^{\text {nd }}$ and $3^{\text {rd }}$ instars was 2 days, and for the $4^{\text {th }}$ 
instars and pupal stage 1-2 days. Mean adult longevity of B and A biotype was 5.42 and 4.55 days, respectively. Thus, A biotype had a shorter life cycle and longer adults' longevity than B biotype. Similar results were found for immature stages and adult longevities, percentages of survival, sex ratio of B and A biotype on rapeseed.

Table 1 - Development (in days) of B (Bemisia argentifolii) and A (Bemisia tabaci) biotype reared on cotton at $24^{\circ} \mathrm{C}$. Numbers between brackets represent standard error.

\begin{tabular}{ccccccccc}
\hline Species & $\begin{array}{c}\text { Egg } \\
\text { Duration (day) }\end{array}$ & $\begin{array}{c}\mathbf{1}^{\text {st }} \text { instar } \\
\text { (day) }\end{array}$ & $\mathbf{2}^{\text {nd }}$ instar $\mathbf{3}^{\text {rd }}$ instar $\mathbf{4}^{\text {th }}$ instar & Pupae & Total preadult & $\begin{array}{c}\text { Adult } \\
\text { (day) } \\
\text { (day) }\end{array}$ \\
(days) & duration(day) & longivity(day) \\
\hline B biotype & $10.75(0.62)$ & $4.75(0.25)$ & $2(0.0)$ & $2(0.0)$ & $1.5(0.28)$ & $1.5(0.28)$ & $22.25(0.6)$ & $5.42(0.55)$ \\
A biotype & $10.58(0.25)$ & $4.25(0.25)$ & $2(0.0)$ & $2(0.0)$ & $1.5(0.28)$ & $1.25(0.25)$ & $22.08(0.22)$ & $4.55(0.2)$ \\
\hline
\end{tabular}

The results of total female eggs per female per day $\left(\right.$ Gross fecundity- $\left.\mathrm{m}_{\mathrm{x}}\right)$ are shown in Figure 1 . The maximum egg laid, its day of occurrence and the end of oviposition period for B biotype females, which were collected from the rapeseed and cotton were $5.64,29.5$ and $42.5 ; 1.93,28.5$ and 47.5, respectively. The maximum egg laid; its day of occurrence and the end of oviposition period for A biotype females, which were collected from the rapeseed and cotton were 3.25, 28.5 and 38.5; $2.83,43.5$ and 47.5 , respectively.

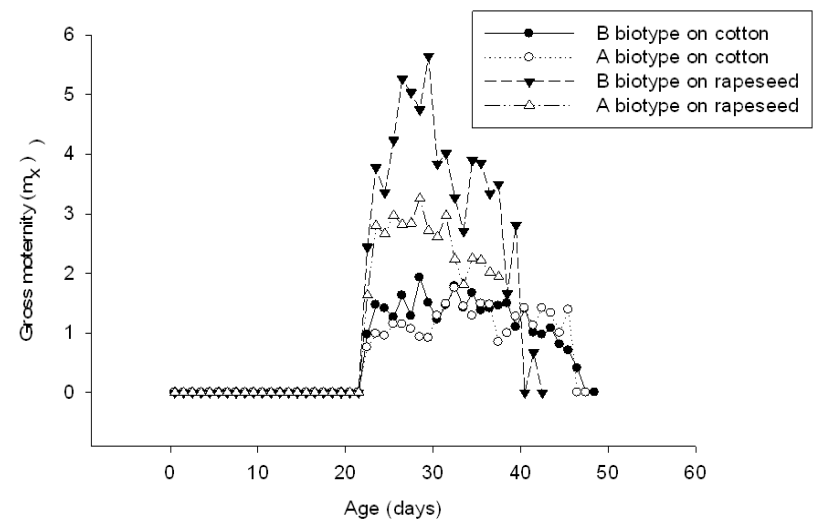

Figure 1 - Mean of female eggs per female per day $\left(\mathrm{m}_{\mathrm{x}}\right)$ when $\mathrm{A}$ and $\mathrm{B}$ biotype were reared on rapeseed and cotton

\section{Life table and demographic parameters}

Results showed the significant difference between the host plant per biotype for Gross Reproductive Rate (GRR) (d.f. $=3, F=3719, p=0.001)$. Net Reproductive Rate $\left(\mathrm{R}_{0}\right)$ (d.f. $=3, F=2083, p=$ $0.000)$, Intrinsic Rate of Increase $\left(\mathrm{r}_{\mathrm{m}}\right)$ (jackknife estimate of $r_{m}$ ) (d.f $=3, F=82.86, p=0.000$ ), Finite Rate of Increase $(\lambda)$, (d.f $.=3, F=85.38, p$ $=0.000$ ), Doubling Time (DT) (d.f. $=3, F=$ 43.59, $p=0.000)$ and Mean Generation Time (T) (d.f. $=3, F=22.79, p=0.000$ ) at the $1 \%$ probability level indicated that the host plants had a significant impact on biological performance of both studied whiteflies. As shown in Table 2, the populations, which were reared on rapeseed had a significant higher value for the intrinsic rate of increase, finite rate of increase, gross reproductive rate and net reproductive rate than those, which were reared on the cotton, This showed that rapeseed was a more suitable host for the development and reproduction of two biotype than cotton. Furthermore, these life parameter values for B biotype fed on rapeseed were significantly higher than A biotype. Besides, doubling time and generation time for B biotype were the lowest with 3.97 and 21.27 days, respectively in comparison with other populations.

Table 2 - Means of population parameters of B (Bemisia argentifolii) and A biotype reared on rapeseed and cotton (Numbers between brackets represent standard error).

\begin{tabular}{llccc}
\hline \multicolumn{1}{c}{ Variable } & $\begin{array}{c}\text { B biotype reared } \\
\text { on rapeseed }\end{array}$ & $\begin{array}{c}\text { B biotype reared } \\
\text { on cotton }\end{array}$ & $\begin{array}{c}\text { A biotype reared } \\
\text { on rapeseed }\end{array}$ & $\begin{array}{c}\text { A biotype reared } \\
\text { on cotton }\end{array}$ \\
\hline $\begin{array}{l}\text { Gross reproductive rate }(\mathrm{GRR}) \\
\text { (eggs per female) }\end{array}$ & $68.00(0.41) \mathrm{a}$ & $32.22(0.2126) \mathrm{c}$ & $43.57(0.254) \mathrm{b}$ & $30.5(0.212) \mathrm{d}$ \\
\hline $\begin{array}{l}\text { Net reproductive rate }\left(\mathrm{R}_{\mathrm{o}}\right) \\
\text { (female/female/ generation) }\end{array}$ & $40.75(0.256) \mathrm{a}$ & $27.84(0.196) \mathrm{c}$ & $30.47(0.127) \mathrm{b}$ & $18.41(0.2) \mathrm{d}$ \\
\hline Intrinsic rate of increase $(\mathrm{r})(1 / \mathrm{t})$ & $0.175(0.0027) \mathrm{a}$ & $0.103(0.003) \mathrm{c}$ & $0.128(0.002) \mathrm{b}$ & $0.101(0.005) \mathrm{c}$ \\
\hline Finite rate of increase $(\lambda)($ day $)$ & $1.191(0.003) \mathrm{a}$ & $1.109(0.0037) \mathrm{c}$ & $1.137(0.003) \mathrm{b}$ & $1.106(0.0061) \mathrm{c}$ \\
\hline Doubling Time $(\mathrm{DT})($ day) & $3.97(0.062) \mathrm{c}$ & $6.81(.22) \mathrm{a}$ & $5.42(0.11) \mathrm{b}$ & $7.14(0.35) \mathrm{a}$ \\
\hline Mean generation time $(\mathrm{T})($ day $)$ & $21.27(0.36) \mathrm{c}$ & $32.74(1.12) \mathrm{a}$ & $26.77(0.6) \mathrm{b}$ & $30.07(1.59) \mathrm{a}$ \\
\hline
\end{tabular}

Similar letters in rows indicate no significant difference at the level of 5\% according to LSD and Duncan's test. 
The means of stable age distribution $\left(\mathrm{C}_{\mathrm{x}}\right)$ (in different age classes; egg stage, settled $1^{\text {st }}$ instars, $2^{\text {nd }}$ instars, $3^{\text {rd }}$ instars, $4^{\text {th }}$ instars and pupa) were $0.65,0.14,0.048,0.038,0.03$ and 0.022 for $\mathrm{B}$ biotype and $0.58,0.15,0.055,0.05,0.042$ and
0.012 for A biotype, respectively when both biotype were reared on cotton. Proportions for preimaginal period and adult periods were 0.93 and 0.07 for B biotype; 0.91 and 0.082 for cotton whitefly, respectively (Table 3 ).

Table 3 - Stable age distribution coeficients (Cx) of B and A biotype of Bemisia tabaci reared on cotton at $24^{\circ} \mathrm{C}$.

\begin{tabular}{ccccccccc}
\hline Species & $\begin{array}{c}\text { Incubation } \\
\text { period }\end{array}$ & $\mathbf{1}^{\text {st }}$ instar & $\mathbf{2}^{\text {nd }}$ instar & $\mathbf{3}^{\text {rd }}$ instar & $\mathbf{4}^{\text {th }}$ instar & Pupae & $\begin{array}{c}\text { Preimaginal } \\
\text { period }\end{array}$ & Adult \\
\hline B biotype & 0.65 & 0.14 & 0.048 & 0.038 & 0.03 & 0.022 & 0.93 & 0.07 \\
A biotype & 0.58 & 0.15 & 0.055 & 0.05 & 0.042 & 0.012 & 0.91 & 0.082 \\
\hline
\end{tabular}

\section{DISCUSSION}

Pest species of insects are notoriously prone to escape the tools deployed in the management efforts against them. This is particularly true in herbivorous insects (Downie 2010). When a previously successful tactic fails, the insect population apparently adapts to it and is often considered to be a new or distinct entity, and is given the non-formal category 'biotype'. The entities falling under the umbrella term 'biotype' are not consistent either within or between the biotypes and their underlying genetic composition and origins, while generally unknown, are likely heterogeneous within and variable between the biotypes. In some cases, race or species may be more appropriate referents. Some examples of applications of the concept in the context of host plant resistance are discussed. It is argued that the term 'biotype' and its applications are overly simplistic, confused, have not proved useful in current pest management and lack predictive power for future management (Downie 2010).

Samih and Izadi (2006) reported that the two whiteflies species showed significant difference on their gross fecundity and fertility rates and no significant difference on their gross hatch rate, net fecundity and fertility rates, mean age net fecundity and fertility, eggs per female per day and fertile eggs per female per day. They believed that oviposition range of $B$. tabaci based on the temperature, host, plants and insect biotype was significantly variable and showed that the gross fecundity and fertility rates, gross hatch rate, and net fecundity and fertility rates were greater on rapeseed than on cotton.

The developmental times of B biotype (22.28 d) reared on cotton in this study were nearly equal to those reared on cotton $(23.6 \mathrm{~d})$ and poinsettia (23.2 d) at about $25^{\circ} \mathrm{C}$ (Bethke et al. 1991) and on sweet pepper $\left(21.5\right.$ d) at $26^{\circ} \mathrm{C}$ (Muniz and Nombela 2001). The fecundity of B biotype reared on rapeseed (68 eggs) was higher than on cotton (51.2 eggs) (Bethke et al. 1991) and less than on poinsettia (85.0 eggs) (Bethke et al. 1991), tobacco (72.3 eggs) (Enkegaard 1993) at about $25^{\circ} \mathrm{C}$, and on alfalfa, broccoli, cantaloupe, cotton and zucchini (40.6 - 70.6 eggs) at $27^{\circ} \mathrm{C}$ (Yee and Toscano 1996). This study demonstrated that the type of host plant had a significant effect on the development, survival and reproduction of B and A biotype. These findings generaly agreed with other related studies about these whitefly biotype (Coudriet et al. 1985; Bethke et al. 1991; Powell and Bellows 1992a, b; Enkegaar 1993; Simmons 1994; Yee and Toscano 1996; Nava-Camberos et al. 2001).

Enkegaard (1993) recorded values of $r_{m}, \lambda, T$ and DT for the B strain of $B$. tabaci $(=B$. argentifolii) at $25^{\circ}$ on poinsettia plants as $0.087,1.091,43.0887$ and 7.94, respectively. These values were less than those found for B biotype reared on cotton and rapeseed in the current study. Based on the fact the developmental rate and reproduction was mainly dependent on food quality, food quantity, temperature and kind of host plants, the high values of $r_{m}$ indicated susceptibility of a host plant to insect attacks and vice versa.

Tsai and Wang (1996) compared the suitability of eggplant, cucumber, tomato, sweet potato and garden bean for a Florida population of $B$. argentifolii. They reported that the pest intrinsic rates of increase (r) on these hosts, was 0.192, $0.153,0.138,0.134$ and 0.12 , respectively at $25^{\circ}$, $80-90 \% \mathrm{RH}$ and a 14L10D h photoperiod though these values were higher than those that obtained in the present study for a $B$. argentifolii population collected in Iran.

Cui et al. (2008) investigated the effects of heat shock on two whitefly species, Teialeurodes 
vaporariorum (Westwood) and B. tabaci biotype $B$ and showed the significance of heat shock in relation to dispersal, distribution and population dynamics of the two whitefly species. Gou et al. (2012) demonstrated the ability of B. tabaci biotype $\mathrm{B}$ to survive long-term high-temperature stress, which were important for understanding its population distribution under global warming. Musa and Ren (2005) stated that the developmental period from the egg to adult varied from 27.8 days on garden beans to 18.2 days on soybeans. They also showed that the fecundity of B. tabaci on soybean, cowpea and garden bean were $160.85 \pm 19.04,153.07 \pm 15.65$ and $98 \pm$ 13.02, respectively. The intrinsic rate of increase $\left(r_{m}\right)$, finite rate of increase $(\lambda)$ and net reproductive rate $\left(\mathrm{R}_{0}\right)$ on soybeans were $0.1875,1.2041$ and 82.15 , respectively. Present study showed that A biotype was less adapted to rapeseed and cotton than soybean in the study by Musa and Ren (2005). On the other hand, A biotype was highly adapted and showed the greater preference for soybean than rapeseed and cotton.

Yang and Chi (2006) studied the life history of $B$. argentifolii on tomato based on the age-stage, twosex life table at $15,20,25,28,30$, and $35^{\circ} \mathrm{C}$ and found its intrinsic rate of increase $(r)$ as 0.1469 at $25^{\circ} \mathrm{C}$, which was different with the present results. On the other hand, they mentioned that the mean generation time of $B$. argentifolii on tomato at $25^{\circ} \mathrm{C}$ was 28.4 , which was closer to the mean value of the present study. Also, $r_{m}$ of A biotype decreased on both the hosts, while $r_{m}$ of B biotype increased only when it was reared on rapeseed and decreased when reared on cotton. The recent results were similar to Yang and Chi (2006) when $B$. argentifolii was reared on tomato. The intrinsic rate of natural increase $\left(r_{m}\right)$ of B biotype $(B$. argentifolii) and $\mathrm{A}$ biotype reared on cotton $(0.1033$ and 0.1010 , respectively) in this study was closed to Lin and Ren (2005) results on B biotype of B. tabaci reared on cotton rose hibiscus (Hibiscus mutabilis L.) $(0.1032)$ at $26 \pm 2^{\circ} \mathrm{C}$, related humidity of $75-90 \%$ and a photoperiod of $14: 10 \mathrm{~h}(\mathrm{~L}: \mathrm{D})$. They showed that, in comparison with tomato, cotton rose hibiscus and cotton, rapeseed was the most suitable host plant for $B$. argentifolii.

Calvitti and Remotti (1998) found that the intrinsic rate of increase of $B$, argentifolii varied from 0.11 on $S$. oleraceous to 0.004 for Euphorbia dendroides, which meant that $B$. argentifolii established its colony on wild plants in the absence of cultivated host plants such as tomato, squash, ornamental plants, poinsettia, cotton and rapeseed. The present results demonstrated that this pest attack to rapeseed also occurred in the absence of main host same as cotton. Luo et al. (2008) reported the developmental times between 20.8 to $24.2 \mathrm{~d}$ and the intrinsic rate of natural increase $\left(r_{m}\right)$ between 0.0844 to 0.1121 for $B$. argentifolii when it reared on six cotton cultivars at $27 \pm 1^{\circ} \mathrm{C}$. This was closer to the present results (23.75 and 0.1033, respectively). Also, Bethke et al. (1991) reported that the developmental times of $B$. argentifolii reared on cotton and poinsettia were 23.6 and 23.2 days at about $25^{\circ} \mathrm{C}$, which was very close to the present report $(23.75 \mathrm{~d})$. This was 21.5 $\mathrm{d}$ on sweet pepper at $26^{\circ} \mathrm{C}$ (Muniz and Nombela 2001).

Kakimoto et al. (2007) studied the developmental time, intrinsic rate of natural increase $\left(r_{m}\right)$, net reproductive rate $\left(R_{0}\right)$ and the mean life time fecundity of $B$. argentifolii raised on four commercial vegetables such as eggplant, cucumber, sweet pepper and tomato at $25^{\circ} \mathrm{C}$. They found the developmental time of pest as $21.8 \mathrm{~d}$ on eggplant, $22.4 \mathrm{~d}$ on cucumber, $22.7 \mathrm{~d}$ on sweet peper and $25.6 \mathrm{~d}$ on tomato. In comparing with the present work, this parameter on cotton and rapeseed was shorter than on tomato while was longer on other vegetables. They mentioned that the intrinsic rate of natural increase $\left(r_{m}\right)$ and net reproductive rate $\left(R_{0}\right)$ was 0.168 and 185.1 on eggplant; 0.153 and 130.7 on cucumber; 0.143 and 73.1 on sweet pepper; and 0.110 and 36.1 on tomato, respectively. In this study, the $r_{m}$ of reared B biotype was decreased on cotton when it was compared with the reared one on rapeseed while it was higher than all these vegetables. Also, the mean life-time fecundity of $B$. argentifolii on eggplant, cucumber, sweet pepper and tomato were 221.3, 167.6, 92.3 and 62.9 eggs, respectively. In this study, the life-time fecundity for B biotype reared on rapeseed was higher than tomato while was lower than on the other vegetables, but it was much lower on cotton and rapeseed than all other plants for A biotype. The results Kakimoto et al. (2007) in comparing with the present work showed that eggplant, cucumber and sweet pepper were more suitable host plants for $B$. argentifolii than rapeseed and cotton.

Liu and Stansly (1998) reported the intrinsic rate of increase (r) and finite rate of increase $(\lambda)$ of $B$. argentifolii reared on Hibiscus rosa-sinensis that were 0.105 and 1.22 , respectively. Certainly, all 
values of $\mathrm{r}_{\mathrm{m}}$ for $B$. argentifolii, which were recorded by Liu and Stansly (1998), Yang and Chi (2006), Kakimoto et al. (2007) Luo et al. (2008) and this work showed that $H$. rosa- sinensis and cotton were poor hosts for $B$. argentifolii in comparing with other hosts such as eggplant, tomato, sweet potato, cucumber, garden bean and rapeseed. Based on the present findings, the fecundity of B biotype (68 eggs) reared on rapeseed was higher than on cotton (51.2 eggs), but it was lower than on poinsettia (85.0 eggs) (Bethke et al. 1991) and tobacco (72.3 eggs) (Enkegaard 1993) at about $25^{\circ} \mathrm{C}$. Yee and Toscano (1996) reported the range of $40.6-70.6$ eggs for alfalfa, broccoli, cantaloupe, zucchini and cotton at $27^{\circ} \mathrm{C}$. The intrinsic rate of natural increase $\left(\mathrm{r}_{\mathrm{m}}\right)$ of $\mathrm{B}$ biotype and A reared on cotton (0.1033 and 0.1010 , respectively) in present study were almost equal to $\mathrm{r}_{\mathrm{m}}$ for Q-biotype of $B$. tabaci reared on tomato $(0.106)$ at $25 \pm 1^{\circ} \mathrm{C}, 60 \pm 5 \% \mathrm{RH}$ and L14:D10 h (Bonato et al. 2007).

\section{ACKNOWLEDGMENTS}

The authors are most grateful to Professor P. De Clercq (Dept. of Crop Protection, Lab. of Agroecology, university of Gent, Belgium), and K. Mahdian (Dept. of plant Protection, Faculty of Agriculture, Vali-e- Asr University, Iran) for their valuable contributions to this paper.

\section{REFERENCES}

Bellows J, Perring TM, Gill RG, Headrick DH. Description of a species of Bemisia (Homoptera: Aleyrodidae). Ann Entomol Soc Am. 1994; 87: 195206.

Bethke JA, Paine TD, Nuessly GS. Comparative biology, morphometrics and development of two populations of Bemisia tabaci (Hom.: Aleyrodidae) on cotton and poinsettia. Ann Entomol Soc Am. 1991; 84: 407-411.

Birch LC. The intrinsic rate of natural increase in an insect population. J Anim Ecol. 1948; 17: 15-26.

Bonato O, Lurette A, Vidal C, Fargues J. Modelling temperature-dependent bionomics of Bemisia tabaci (Q-biotype). Physiol Entomol. 2007; 32: 50-55.

Brown JK, Frohlich DR, Rosell RC. The sweetpotato or silverleaf whiteflies biotypes of Bemisia tabaci or a species complex. Ann Rev Entomol. 1995; 40: 511534.
Byrne DN, Miller WB. Carbohydrate and amino acid composition of phloem sap and honeydew produced by Bemisia tabaci. J Insect Physiol. 1990; 36: 433439.

Calvitti M, Remotti PC. Host preference and performance of Bemisia argentifolii (Homoptera: Aleyrodidae) on weeds in central Italy. Environ Entomol. 1998; 27: 1350-1356.

Carey JR. Applied demography for biologists with special emphasis on insects. New York: Oxford University Press; 1993.

Coudriet DL, Meyerdrik DE, Prabhaker N, Kishaba AN. Variation in developmental rate on different hosts and overwintering of the sweetpotato whitefly Bemisia tabaci (Genn.) (Homoptera: Aleyrodidae). Environ Entomol. 1985; 14: 516-519.

Cui XH, Wan FH, Xie M, Liu TX. Effects of heat shock on survival and reproduction of two whitefly species, Trialeurodes vaporariorum and Bemisia tabaci biotype B. J Insect Sci. 2008; 8: 24, 1-10.

De Barro PJ, Liu SS, Boykin LM, Dinsdale AB. Bemisia tabaci: a statement of species status. Annu Rev Entomol. 2011; 56: 1-19.

Dinsdale A, Cook L, Riginos C, Buckley YM, De Barro PJ. Refined Global Analysis of Bemisia tabaci (Hemiptera: Sternorrhyncha: Aleyrodoidea: Aleyrodidae) Mitochondrial Cytochrome Oxidase 1 to Identify Species Level Genetic Boundaries. Ann Entomol Soc Am. 2010; 103: 196-208.

Downie DA. Baubles, bangles, and biotypes: A critical review of the use and abuse of the biotype concept. $J$ Insect Sci. 2010; 10: 1-18

Enkegaard A. The poinsettia-strain of the cotton whitefly Bemisia tabaci (Homoptera: Aleyrodidae) biological and demographic parameters on poinsettia (Euphorbia pulcherima) in relation to temperature. Bull Entomol Res. 1993; 83: 535-546.

Gerling D, Motro U, Horowitz AR. Dynamics of Bemisia tabaci (Genn.) (Homoptera-Aleyrodidae) attaking cotton in the coastal plain of Israel. Bull Entomol Res. 1980; 70: 213-219.

Guo JY, Cong L, Zhou ZS, Wan FH. Multi-generation life tables of Bemisia tabaci (Gennadius) biotype B (Hemiptera: Aleyrodidae) under high-temperature stress. Environ Entomol. 2012; 41: 1672-1679.

Headrick DH, Bellows TS, Perring TM. Development and reproduction of a population of Eretmocerus eremicus (Hymenoptera: Aphelinidae) on Bemisia argentifolii (Homoptera: Aleyrodidae). Environ Entomol. 1999; 28: 300-306.

Jones D. Plant viruses transmitted by whiteflies. Eur $J$ Plant Pathol. 2003; 109: 195-219.

Kakimoto K, Inoue H, Yamaguchi T, Ueda S, Honda K, Yano E. Host plant effect on development and reproduction of Bemisia argentifolii Bellows and Perring (B. tabaci [Gennadius] B-biotype) (Homoptera: Aleyrodidae). Appl Entomol Zool. 2007; 42: 63-70. 
Kiriukhin G. Quelques Aleurododea de l'Iran. Entomologie Phytopath Appl. 1947; 5: 8- 10 (In Persian, 5: 22-28; French summary).

Lin CS. The theory and experiment study of animal population change the innate capacity for increase of Tribolium confusum (H.). Acta Zoologica Sinica. 1964; 16: 323-328.

Lin L, Ren SX. Development and reproduction of 'B' biotype Bemisia tabaci (Gennadius) (Homoptera: Aleyrodidae) on four ornamentals. J Insect Sci. 2005; 12: 137-142.

Liu T, Stansly PA. Life history of Bemisia argentifolii (Homoptera: Aleyrodidae) on Hibiscus rosa-sinensis (Malvaceae). Florida Entomol. 1998; 81: 437-445.

Luo C, Gao QG, Mo TL, Zhang F, Zhang ZL. Development, Longevity, Fecundity, and Survivorship of Bemisia tabaci (Gennadius) Biotype 'B' on Six Cotton Cultivars. J Insect Sci. 2008; 8: 2929.

Maia AHN, Luiz AJB, Campanhola C. Statistical influence on associated fertility life table parameters using jackknife technique, computational aspects. $J$ Econ Entomol. 2000; 93: 511-518.

Meyer JS, Igersoll CG, MacDonald LL, Boyce MS. Estimating uncertainty in population growth rates: jackknifevs bootstrap techniques. Ecology. 1986; 67: 1156-1166.

Mound LA, Halsey SH. Whitefly of the world. A systematic catalogue of the (Homoptera: Aleyrodidae) with host plant and natural enemy data. London: British Museum (Natural History); 1978.

Muniz M, Nombela G. Differential variation in development of the B- and Q-biotypes of Bemisia tabaci (Homoptera: Aleyrodidae) on sweet pepper at constant temperatures. Environ Entomol. 2001; 30: 720-727.

Musa PD, Ren SX. Development and reproduction of Bemisia tabaci (Homoptera: Aleyrodidae) on three bean species. J Insect Sci. 2005; 12: 25-30.

Nava-Camberos U, Riley DG, Harris MK. Densityyield relationships and economic injury levels for Bemisia argentifolii (Homopter: Aleyrodidae) in cantaloupe in Texas. J Econ Entomol. 2001; 94: 180189.

Oliveira MRV, Henneberry TJ, Anderson P. History, current status, and collaborative research projects for Bemisia tabaci. Crop Prot. 2001; 20: 709-723.

Palumbo JC, Toscano NC, Blua MJ, Yoshida HA. Impact of Bemisia whiteflies (Homopter: Aleyrodidae) on Alfalfa growth, forage yield and quality. J Econ Entomol. 2000; 93: 1688-1694.

Perring TM. The Bemisia tabaci species complex. Crop Prot. 2001; 20: 725-737.

Powell DA, Bellows TSJ. Adult longevity, fertility and population growth rates for Bemisia tabaci (Genn.) (Hom., Aleyrodidae) on two host plants. J Appl Entomol. 1992a; 113: 68-78.
Powell DA, Bellows TSJ. Preimaginal development and survival of Bemisia tabaci on cotton and cucumber. Environ Entomol. 1992b; 21: 359-363.

Rosell RC, Bedford ID, Frohlich DR, Gill RJ, Markham PG, Brown JK. Analysis of morphological variation in distinct population of Bemisia tabaci (Homoptera: Aleyrodidae). Ann Entomol Soc Am. 1997; 90: 575589.

Rubinstein G, Morin S, Czosnek H. Transmission of tomato yellow leaf curl geminivirus to imidacloprid treated tomato plants by the whitefly Bemisia tabaci (Homoptera: Aleyrodidae). J Econ Entomol. 1999; 92: 658-662.

Samih MA, Kamali K, Jalali M, Talebi AA. Identification and description of Bemisia tabaci (Genn.) and Bemisia argentifolii Bellows and Perring in cotton fields in Iran using RAPD-PCR technique. $J$ Sci Agric. 2006; 37: 214-224 (in Persian with English summary).

Samih MA, Izadi H. Age specific reproduction parameters of cotton whitefly (Bemisia tabaci) and silverleaf whitefly (B. argentifolii) on cotton and rapeseed. Int J Agric Boil. 2006; 8: 302-305.

Samih MA, Kamali K, Jalali M, Talebi AA. Detection by RAPD-PCR of polymorphism in local populations of sweetpotato whitefly in Iran. Agric Sci. 2007; 17: 151-163. (in Persian with English summary).

Simmons AM. Oviposition on vegetables by Bemisia tabaci (Homoptera: Aleyrodidae): temporal and leaf surface factors. Environ Entomol. 1994; 23: 381-389.

SPSS. SPSS Base 16.0 User's Guide. SPSS Incorporation, Chicago: IL; 2007.

Tsai JH, Wang K. Development and reproduction of Bemisia argentifolii on five host plants. Environ Entomol. 1996; 25: 810-816.

Wang K, Tsai JH. Temperature effect on development and reproduction of silverleaf whitefly (Homoptera: Aleyrodidae). Ann Entomol Soc Am. 1996; 89: 375384.

$\mathrm{Xu}$ J, De Barro PJ, Liu SS. Reproductive incompatibility among genetic groups of Bemisia tabaci supports the proposition that the whitefly is a cryptic species complex. Bull Entomol Res. 2010; 100: 359-366.

Yang T, Chi A. Life Tables and development of Bemisia argentifolii (Homoptera: Aleyrodidae) at different temperatures. J Econ Entomol. 2006; 99: 691-698.

Yano E. Arthropod natural enemies; The ecology and use in biological pest control. Tokyo: Yokendo Ltd., 2003.

Yee WL, Toscano NC. Oviposition preference and development of Bemisia argentifolii (Homoptera; Aleyrodidae) in relation to alfalfa. J Econ Entomol. 1996; 89: 870-876.

Received: May 06, 2013; Accepted: February 10, 2014. 